\title{
Sistem Informasi Pelayanan Poliklinik Pada Klinik Alita Rawalumbu Bekasi
}

\author{
Ridar Setiawan Effendi ${ }^{1}$, Syahbaniar Rofiah ${ }^{1^{\star}}$ \\ ${ }^{1}$ Manajemen Informatika; Universitas Bina Insani; Jl. Siliwangi No. 6 Rawa Panjang, Bekasi \\ Barat, Telp 02188958130; e-mail: 1ridareffendi15@gmail.com, rsyahbaniar@gmail.com \\ *Korespondensi: e-mail: rsyahbaniar@gmail.com
}

Diterima: 22 November 2020; Review: 28 November 2020; Disetujui: 3 Desember 2020

Cara sitasi: Effendi RS, Rofiah S. 2020. Sistem Informasi Pelayanan Poliklinik Pada Klinik Alita Rawalumbu Bekasi. Informatics For Educators And Professionals. 5(1): 73 - 82.

\begin{abstract}
Abstrak: Perkembangan teknologi mempengaruhi pada hardware dan software yang ikut berkembang pesat sehingga dapat memudahkan dalam melakukan pekerjaan. Perkembangan ini sangat menguntungkan bagi bisnis pada pelayanan publik seperti pada sebuah klinik kesehatan. Permasalahan yang dihadapi Klinik Alita sekarang yaitu, dalam kecepatan dan ketepatan dalam melayani publik. Informasi dan data yang diolah bukanlah data yang sedikit. Sistem yang digunakan sekarang adalah dengan memanfaatkan website khusus Badan Penyelenggara Jaminan Sosial (BPJS) yang disediakan oleh Pemerintah untuk pasien khusus yang memiliki Kartu BPJS tetapi untuk pasien umum untuk mengolah informasi masih dicatat secara manual. Penelitian ini bertujuan menghasilkan sistem informasi pelayanan poliklinik yang baru agar digunakan dalam meningkatkan kualitas pelayanan kesehatan di Klinik Alita. Pengembangan sistem informasi pelayanan poliklinik ini berdasarkan hasil observasi, pengumpulan data, perancangan model menggunakan model perancangan berbasis objek, dan aplikasi berbasis website serta metode yang digunakan menggunakan metode prototype. Dengan metode Prototype diharapkan dapat membantu memecahkan masalah yang ada dan dapat membangun sebuah sistem informasi berdasarkan System Development Life Cycle ( $S D L C)$ yang berjalan. Sehingga berdasarkan pembahasan yang telah diuraikan maka dapat dihasilkan suatu sistem informasi pelayanan poliklinik berbasis website yang dapat mendukung pelayanan yang pada Klinik Alita serta dapat memecahkan masalah-masalah yang ada.
\end{abstract}

Kata kunci: bootstrap, pasien, pelayanan, poliklinik, prototype

\begin{abstract}
Technology developments affect the hardware and software that is developing rapidly so that it can facilitate the work. This development is very beneficial for businesses in public services such as a health clinic. The problem faced by Alita Clinic now is in the speed and accuracy in serving the public. Information and data that is processed is not little data. The system used now is to utilize a special Social Security Administrator (BPJS) website provided by the Government for special patients who have a BPJS Card but for general patients to process information it is still recorded manually. This study aims to produce a new polyclinic service information system so that it can be used to improve the quality of health services at Alita Clinic. The development of this polyclinic service information system is based on observations, data collection, design models using object-based design models, and website-based applications and methods used using prototype methods. With the Prototype method it is expected to help solve existing problems and be able to build an information system based on the running System Development Life Cycle (SDLC). So based on the discussion that has been described, a website-based polyclinic service information system can be produced that can support the services at Alita Clinic and can solve existing problem.
\end{abstract}

Keywords: bootstrap, patient, polyclinic, prototype, service 


\section{Pendahuluan}

Pada era globalisasi saat ini perkembangan teknologi informasi sangat pesat terutama dalam berbagai bidang salah satunya adalah dibidang pelayanan publik seperti yang ada pada klinik. Perkembangan tersebut juga mempengaruhi pada perangkat lunak dan perangkat keras yang juga ikut berkembang sangat pesat sehingga dapat memudahkan manusia dalam melakukan pekerjaannya. Perkembangan ini tentu sangat menguntungkan bagi bisnis - bisnis besar seperti bisnis pada pelayanan publik seperti yang ada pada klinik. Setiap klinik pasti ingin meningkatkan kinerja pelayanan mereka yang berdampak penting bagi pendapatan mereka. Oleh karena itu setiap klinik akan mengambil keputusan-keputusan yang ditujukan untuk meningkatkan pelayanan kepada publik serta hak akses kepada publik. Strategi bisnis untuk meningkatkan pelayanan publik secara cepat dan tepat membuat harus adanya sebuah sistem yang melayani hal tersebut berupa pelayanan poliklinik berbasis website.

Pelayanan adalah sebuah proses pemenuhan kebutuhan dengan memerlukan keterlibatan pihak lain, dengan melalui suatu proses dan prosedur tertentu sampai kebutuhan yang dimaksud dapat dimanfaatkan (dikonsumsi) oleh yang membutuhkannya [1].

Klinik Alita merupakan salah satu klinik umum yang aktif di Kota Bekasi yang selalu mengutamakan pelayanan dan mutu pelayanan yang maksimal kepada setiap pasien dan keluarga pasien (pelanggan). Permasalahan yang dihadapi Klinik Alita saat ini yaitu, masalah dalam hal ketepatan dalam pengolahan informasi dan data. Informasi dan data yang diolah bukanlah data yang sedikit salah satu contohnya adalah data pasien. Dimana data pasien meliputi data pendaftaran pasien, data diri pasien, data pembayaran pasien, data resep pasien serta data rekam medis pasien. Semakin banyaknya data atau informasi yang diolah secara bersamaan maka waktu yang dibutuhkan untuk memproses data tersebut juga akan semakin lama serta ketepatan informasi juga mungkin akan berkurang jika hanya bergantung kepada satu sistem.

Sistem yang digunakan saat ini adalah dengan memanfaatkan website khusus BPJS yang disediakan oleh Pemerintah untuk pasien khusus yang memiliki Kartu BPJS tetapi untuk pasien umum untuk mengolah informasi masih dicatat secara manual salah satu contohnya adalah data rekam medis pasien yang dicatat manual serta data pendaftaran pasien dan kartu pasien yang harus masih dicatat manual. Sehingga diperlukan sistem yang baru untuk mendukung sistem yang lama agar sistem yang lama tidak terlalu terbebani dan menjaga agar data tetap aman dan dapat tersimpan dengan baik.

Codelgniter merupakan toolkit bagi orang yang ingin membangun aplikasi web menggunakan PHP dengan tujuan membuat pengembangan proyek menjadi lebih cepat dibandingkan dengan menulis kode dari awal (scratch) yang menggunakan kaidah MVC (Model, View, Controller) [2]. Bootstrap adalah sebuah alat bantu untuk membuat sebuah tampilan halaman website yang dapat mempercepat pekerjaan seorang pengembang website ataupun pendesain halaman website [3]. PHP Hypertext Preprocessor (PHP) suatu bahasa pemrograman yang digunakan untuk menerjemahkan baris kode program menjadi kode mesin yang dapat dimengerti oleh komputer yang bersifat server-side yang dapat ditambahkan ke dalam HTML [4].

Dalam penelitian sebelumnya diantaranya untuk menunjang pelayanan kesehatan dan pengolahan data rekam medis pasien di klinik griya medika, diperlukan sebuah sistem informasi rekam. Pencatatan dan pengolahan data rekam medis yang ada berjalan kurang optimal, dikarenakan masih dilakukan secara manual dengan menggunakan aplikasi spreadsheet, sehingga ketika petugas melakukan indexing dan menyusun laporan mengalami kesulitan, karena petugas harus merekap dan mencari kembali data yang akan dibutuhkan. Tujuan penelitian ini adalah melakukan pengembangan sistem, dengan membuat rancangan sistem informasi rekam medis. Jenis penelitian ini adalah penelitian developmental System dengan menggunakan pendekatan kualitatif. Dalam penelitian ini, proses pengumpulan dan pengambilan data dilakukan dengan menggunakan teknik purposive sampling. Dari hasil identifikasi user, peneliti mulai merancang data flow diagram (DFD), entity relationship diagram $(E R D)$, basis data dan desain interface sistem, serta bentuk cetak laporan yang dihasilkan. Dengan adanya rancangan sistem ini, diharapkan dapat bermanfaat bagi institusi. Namun rancangan sistem ini masih banyak kekurangan dan kedepannya perlu dilakukan beberapa perbaikan [5]. 
Pengelolaan poliklinik saat ini umumnya sudah menggunakan sistem terkomputerisasi. Namun, sistem yang sudah ada hampir seluruhnya dibuat terpisah atau dalam bentuk sistem yang berdirisendiri. Pengelolaan data klinik, data keuangan, data apotik dan data antrian dipakai dengan sistem yang berbeda-beda. Berdasarkan penelitian-penelitian sebelumnya telah ada sistem informasi klinik, rekam medis, dan rawat inap/jalan namun aplikasi tersebut masih berdiri sendiri. Terdapat banyak rujukan penelitian sebelumnya yang hanya mengelolah data klinik dalam hal ini rekam medis dan data-data apotik. Pengelolaan keuangan belum pernah dipadukan dalam sistem yang sama khususnya untuk sistem informasi poliklinik. Solusi yang diberikan oleh peneliti dengan merancang dan membangun sistem yang memadukan pengelolaan data klinik, data perawatan, data keuangan, data apotik, serta data antrian dalam satu sistem yang terpadu. Pengembangan sistem memanfaatkan teknologi web seperti: bahasa pemrograman PHP, HTML5, CSS, dan Javascript. Penyimpanan data dirancang dengan memanfaatkan database server MySQL. Pemanfaatan teknologi web ini memungkinkan sistem berjalan ringan dan dapat diakses baik secara intranet maupun internet [6].

Klinik sebagai salah satu instansi yang memberikan layanan kesehatan kepada masyarakat umum yang memerlukan adanya suatu sistem informasi. Dalam memberikan layanan dan informasi pada Klinik Annisa Medika 2 masih belum menggunakan sistem yang terkomputerisasi. Layanan tersebut misalnya: pendaftaran pasien masih dilakukan dengan cara pasien harus datang langsung ke klinik, tidak memiliki sistem antrian dalam berobat, beberapa pasien yang ingin melakukan konsultasi kesehatan sering mengalami kekecewaan, dan pengelolaan data medis pasien (medical record) yang mempunyai banyak kelemahan seperti sulitnya mencari berkas, memungkinkan terjadinya kerusakan dan kesalahan penulisan serta pembacaannya. Oleh karena itu, dibangun sebuah sistem informasi pelayanan klinik berbasis web dengan menggunakan framework laravel dengan desain MVC (Model-View-Controller) yang dapat memberikan informasi mengenai pendaftaran berobat, antrian berobat menggunakan queue with priority dengan ketentuan prioritas yaitu daftar online, offline, dan nomor kursi. Pengujian sistem dilakukan dengan 2 cara yakni pengujian black box dan statisfaction scale. Dari hasil pengujian black box yang sudah dilakukan berdasarkan 33 butir uji menunjukkan bahwa sistem sudah $100 \%$ berhasil dibangun sesuai dengan yang diharapkan. Begitu pula hasil pengujian statisfaction scale dengan mengukur pemahaman seberapa puaskah pengguna dalam menggunakan software yang telah dibuat menunjukkan bahwa ratarata kepuasan pasien yaitu 0.03 , kepuasan dokter yaitu 0.13 dan kepuasan petugas yaitu 0.39 dengan nilai besar dari 0 , semakin besar nilainya maka kualifikasinya dinilai semakin baik [7].

Dalam membangun sebuah sistem informasi sebuah data yang dipergunakan sebagai alat untuk mendefinisikan kebutuhan-kebutuhan tentang database suatu organisasi yang digunakan untuk menggambarkan objek-objek dalam bentuk entitas dan relasinya berdasarkan permintaan dari pemakai dapat digambarkan oleh sebuah Entity Relationship Diagram [8]. Dalam membangun sebuah program, bahasa yang saat ini banyak digunakan adalah Hypertext Preprocessor atau PHP, source code dari program PHP tetap dalam bentuk file teks murni dan langsung bisa di parser oleh software PHP di server tanpa harus diubah ke bentuk lainnya terlebih dahulu seperti file executable [9].

Berdasarkan latar belakang masalah tersebut, maka dapat di rumuskan beberapa permasalahan, sebagai berikut: 1) Bagaimana cara meningkatkan ketepatan dalam pengolahan data atau informasi di Klink Alita ?, 2) Bagaimana memproses dan mengolah data atau informasi dalam jumlah banyak secara bersamaan yang akurat ?, 3) Bagaimana membuat sistem yang baru yang tidak mudah terbebani ? 4) Bagaimana menjaga data - data klinik agar data tetap aman dan tersimpan dengan baik ?.

Untuk mengatasi permasalahan tersebut perlu adanya sebuah perancangan aplikasi sistem informasi pelayanan poliklinik berbasis website dengan sistem informasi pelayanan poliklinik berbasis website tersebut pihak klinik dapat memperoleh informasi dengan lebih tepat serta dalam memproses data atau informasi yang ada dapat lebih akurat dan tidak memakan waktu yang lama dan dapat menghasilkan output dalam waktu singkat dan akurat. Serta menjaga agar data tersimpan dengan baik dan aman. Dengan menggunakan metode Prototype diharapkan dapat membantu memecahkan masalah yang ada Berdasarkan sistem yang pernah dibuat sebelumnya menggunakan metode Prototype maka untuk pembuatan sistem ini juga masih akan menggunakan metode yang sama yakni metode Prototype. 


\section{Metode Penelitian}

Metode penelitian digunakan dengan tujuan memudahkan mendapatkan informasi pada penelitian, teknik pengumpulan data yang terdiri dari observasi dengan melihat dan mengamati proses sistem yang sedang berjalan yang ada pada Klinik Alita. Melakukan wawancara secara langsung dengan petugas klinik dan manajer klinik untuk mendapatkan data yang benar dan akurat serta mendapatkan informasi yang baru yang sebelumnya tidak didapatkan saat melakukan observasi. Studi pustaka dari berbagai buku dan jurnal yang berkaitan dengan topik penelitian. Sehingga didapatkan dasar ilmiah yang kuat dalam penyusunan penelitian. Dalam mengembangkan penelitian ini model yang digunakan adalah Prototype. Prototype merupakan sebuah pola yang diambil untuk mengembangkan sebuah sistem perangkat lunak yang memiliki beberapa tahapan, yang terdiri dari analisis kebutuhan, pembuatan prototyping, evaluasi prototyping, pengkodean, evaluasi sistem dan penggunaan sistem. Model Prototype merupakan sebuah metode klasik yang banyak digunakan saat ini. Model Protoype dipilih karena dapat menyambungkan ketidakpahaman pelanggan mengenai hal teknis dan memperjelas spesifikasi kebutuhan yang diinginkan pelanggan kepada pengembang perangkat lunak sehingga pelanggan dapat menjabarkan secara rinci dan lebih detail akan permasalahan dan kebutuhan dari pelanggan itu sendiri.

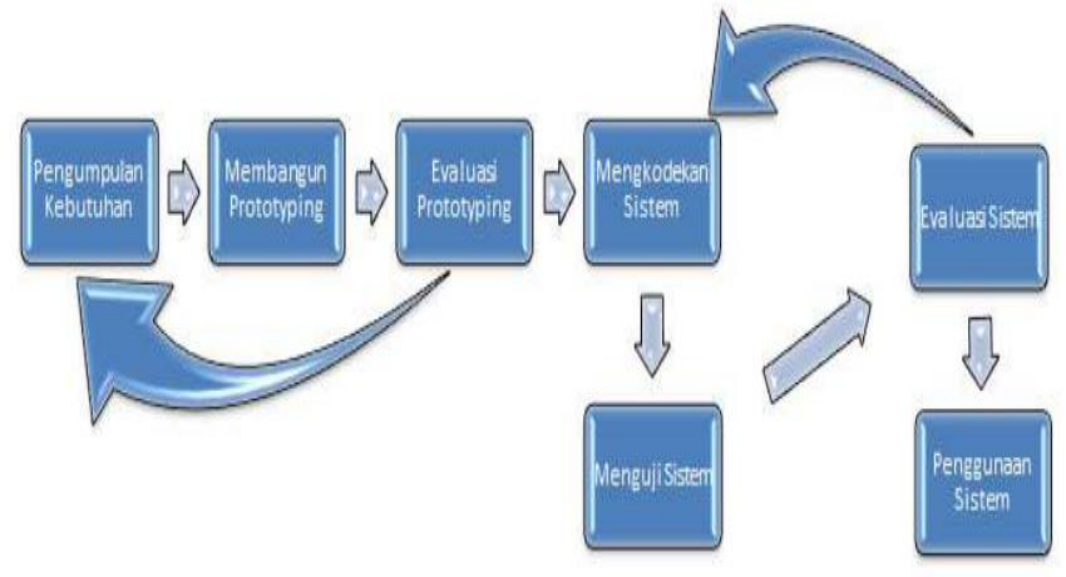

Sumber: Jaya \& Widyawati (2019) [10]

Gambar 1. Ilustrasi Model Prototype

Keterangan gambar 1 sebagai berikut: tahap pertama pengumpulan Kebutuhan, pada tahap ini dalam perancangan piranti lunak, perlu mengetahui karakteristik dasar dari piranti lunak yang akan dirancang, seperti fungsi, bentuk, dan tampilan dari piranti lunak tersebut. Proses dalam mencari kebutuhan difokuskan kepada software.Berdasarkan hasil observasi dan wawancara secara langsung, selanjutnya dapat menganalisis data permasalah yang dihadapi user. Apakah kebutuhan dari fungsi sebuah software untuk memenuhi kendala yang dihadapi oleh user. Sehingga akan didapatkan sebuah dokumen analisis yang digunakan untuk diberikan kepada user. Analisis kebutuhan dilakukan dengan memperhatikan segala aspek mulai dari aspek klinik tersebut pasien yang datang untuk berobat karyawan yang nantinya akan menjalankan aplikasi tersebut dan juga beberapa komponen yang terlibat seperti dokter dan juga apoteker. Tahap kedua, membangun Prototype, untuk membuat suatu piranti lunak perlu dirancang struktur datanya, arsitektur piranti lunak, detail prosedur, dan karakteristik tampilan yang akan disajikan. Hal itu dilakukan untuk membuat gambaran awal dari aplikasi yang nantinya akan dibuat dimana itu semua bertujuan untuk agar pengembang perangkat lunak tidak kesulitan dalam melakukan pengkodean aplikasi. Setelah mendapatkan dokumentasi yang dibutuhkan dari hasil analisis, maka berikutnya mengubah kebutuhan dari fungsi software diatas menjadi sebuah bentuk "blueprint" software. Sehingga hasil dari analisis akan digunakan untuk membangun sebuah aplikasi. Pembuatan Protoyping dilakukan berdasarkan masukkan dari pengguna dimana pengguna memberikan masukkan soal hal-hal apa saja yang harus ada di dalam aplikasi pelayanan poliklinik. Tahap ketiga, evaluasi prototype, dalam merancang sebuah peranti lunak diperlukan evaluasi yang mendalam apakah dari rancangan awal tersebut sudah sesuai dengan kebutuhan atau tidak Maka sebuah evaluasi sangat penting untuk dilakukan. 
Setelah merancang atau membuat desain awal protoype berdasarkan analisis kebutuhan yang ada maka selanjutnya dilakukan evaluasi Prototype. Evaluasi prototype ini melihat apakah rancangan atau pembuatan awal dari prototype sudah sesuai dengan kebutuhan sistem dari pengguna dimana pengguna menginginkan sebuah sistem pelayanan poliklinik yang mudah digunakan serta sesuai dengan proses bisnis sistem yang berjalan. Tahap keempat, pengodean sistem, agar dapat dimengerti oleh mesin, dalam hal ini yang dimaksud adalah komputer, maka desain yang sebelumnya telah dibuat maka harus diubah bentuknya menjadi bentuk yang dapat dimengerti dan dibaca oleh mesin, yaitu ke dalam bahasa pemrograman melalui proses coding. Pada tahap ini dibangun sebuah aplikasi berdasarkan desain "blueprint" yang telah dibuat. Pengembangan dari aplikasi ini dilakukan dari awal hingga aplikasi siap dijalankan. Dari fungsifungsi yang dibutuhkan hingga muncul tampilan untuk pengguna. Pengodean dilakukan berdasarkan dari analisis dan pembuatan prototyping yang telah dilakukan sebelumnya dimana masukkan dari pengguna sangat dibutuhkan dalam proses pengkodean aplikasi pelayanan poliklinik. Pengodean pada sistem informasi pelayanan poliklinik pada Klinik Alita ini tetap memperhatikan kebutuhan dari Klinik Alita dengan terus berkomunikasi dengan pihak Klinik Alita tentang apa yang mereka mau dan apa yang mereka butuhkan untuk pembuatan sistem informasi pelayanan poliklinik ini. Tahap kelima pengujian sistem, sebuah sistem yang telah dibuat apapun bentuknya maka sistem tersebut perlu diuji apakah sistem tersebut sudah benar dan sudah sesuai dengan permintaan dari user tersebut. pada tahap ini setelah sistem informasi pelayanan poliklinik selesai dibuat maka sistem tersebut akan diuji coba oleh pihak Klinik Alita apakah sistem tersebut sudah sesuai dengan kebutuhan dari Klinik Alita atau tidak. Jika sistem tersebut dirasa masih ada yang kurang maka sistem tersebut akan kembali dilakukan pengodean untuk menambahkan beberapa kekurangan yang ada di tahap pengujian sistem. Tahap keenam evaluasi sistem, sesuatu yang telah selesai dibuat maka harus di evaluasi. Evaluasi sistem bertujuan untuk melihat sudah tepatkah sistem tersebut dibuat sesuai dengan kebutuhan dan desain awal.

Setelah aplikasi siap dan telah melewati tahapan pengujian sistem oleh user maka sebelum sistem tersebut mulai digunakan maka dilakukan sebuah evaluasi untuk mengukur kinerja dari aplikasi sistem informasi pelayanan poliklinik. Evaluasi dilakukan mulai dari menumenu yang ada di dalam aplikasi apakah menu tersebut sudah sesuai dengan fungsinya masing-masing dan apakah menu-menu tersebut bisa digunakan dengan baik. Apabila masih terjadi kesalahan di dalam aplikasi maka pengguna bisa melaporkan hal tersebut kepada pengembang perangkat lunak agar langsung bisa diperbaiki. Evaluasi tersebut bertujuan untuk mengukur kinerja dari sebuah sistem dan menjadi kesempatan terakhir dari seorang user menilai apakah sistem tersebut telah memenuhi semua aspek-aspek yang dibutuhkan oleh user dalam hal ini apakah sistem informasi pelayanan poliklinik pada Klinik Alita ini sudah memenuhi semua aspek yang dibutuhkan oleh Klinik Alita.

Berdasarkan kerangka pemikiran yang telah diuraikan pada gambar 2, maka dapat diuraikan pembahasan masing-masing tahap dalam penelitian adalah sebagai berikut: 1) Identifikasi Masalah, pada tahap ini dilakukan identifikasi masalah pada sistem yang sedang berjalan atau yang sedang digunakan. Dengan demikian, dapat menemukan masalah yang terjadi pada pelayanan terhadap pasien dalam hal kecepatan dan ketepatan, masalah yang terjadi dalam memproses dan mengolah data secara bersamaan, masalah yang terjadi dengan sistem yang lama yang terlalu mudah terbebani dan masalah dalam menjaga data-data agar tetap aman dan tersimpan dengan baik sehingga dapat mencari solusi dari permasalahan tersebut. 2) Pengembangan Perangkat Lunak Metode Prototype, pada tahap ini dilakukan pengembangan perangkat lunak berdasarkan metode apa yang digunakan. Dalam hal ini metode yang digunakan adalah metode Prototype. Dalam membuat sebuah aplikasi menggunakan metode Prototype diperlukan 7 tahapan, yaitu Pengumpulan Kebutuhan, Membangun Prototyping, Evaluasi Prototyping apabila tidak sesuai maka harus kembali ke tahapan Pengumpulan Kebutuhan tapi jika sudah sesuai maka lanjut ke tahapan Mengkodekan Sistem, Menguji Sistem, Evaluasi Sistem apabila tidak sesuai maka harus kembali ke tahap mengkodekan sistem jika sudah sesuai maka lanjut ke tahap Penggunaan Sistem. Dimana dalam tahapan tersebut pengembang membuat berdasarkan kebutuhan dari user dimana apabila prototype yang dibuat tidak sesuai maka tahapan tersebut harus kembali lagi dimulai dari awal. Dengan demikian dapat digunakan untuk mengembangkan perangkat lunak dalam penelitian ini. 3) analisis Sistem, pada tahap ini dilakukan analisis dari sebuah sistem dari 
penelitian yang dilakukan. Mulai dari analisis perusahaan yang berisi tinjauan perusahaan yang berisi sejarah perusahaan dan struktur organisasi serta fungsi dari perusahaan tersebut kemudian proses bisnis sistem yang berjalan dan spesifikasi dokumen sistem berjalan serta analisis kebutuhan hardware dan software. Dengan demikian, dapat menganalisis sistem yang sedang berjalan pada Klinik Alita tersebut. 4) Perancangan Sistem, pada tahap ini dilakukan sebuah perancangan sebuah sistem dari penelitian yang dilakukan. Dengan membuat sebuah desain yang diawali dari membuat sebuah Usecase Diagram, Activity Diagram, Sequence Diagram, Class Diagram kemudian dilanjutkan dengan merancang sebuah Database dengan pengimplementasian ke dalam bentuk sebuah User Interface. Dengan demikian, dapat merancang sebuah sistem berdasarkan langkah-langkah diatas. Perancangan dilakukan berdasarkan hasil dari pengumpulan data serta melakukan penelitian menggunakan metode prototype dimana sistem yang dibangun merupakan dalam bentuk aplikasi berbasis website. 5) Pengkodean, pada tahap ini dilakukan sebuah pengkodean menggunakan bahasa pemrograman. Adapun bahasa pemrograman yang digunakan dalam pengkodean untuk membuat aplikasi adalah bahasa pemrograman PHP dengan Framework yang digunakan adalah Codelgniter. 6). Hasil, pada tahap ini merupakan sebuah hasil dari kerangka pemikiran yang sudah diuraikan sebelumnya. Hasil tersebut Sistem Informasi Pelayanan Poliklinik Berbasis Website Pada Klinik Alita Bekasi.

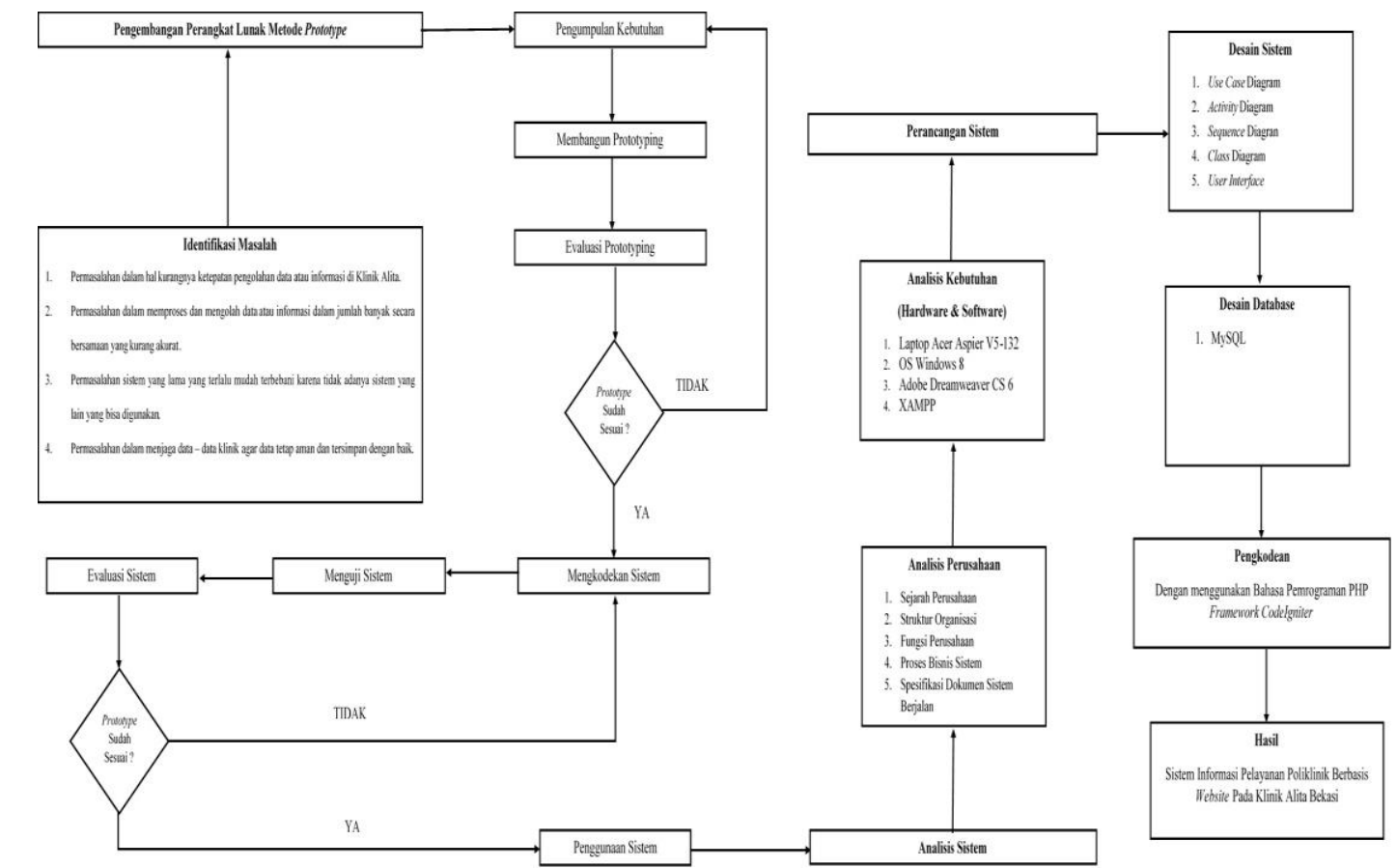

Sumber: Hasil Penelitian (2020)

Gambar 2. Kerangka Pemikiran

\section{Hasil dan Pembahasan}

Klinik Alita berdiri pada tanggal 17 Agustus 1997 di Bekasi. Klinik Alita didirikan oleh seseorang bernama Ibu Winita E. Kusnandar. Pada awalnya Klinik Alita merupakan sebuah poli kesehatan biasa yang didirikan oleh suami dari lbu Winita E. Kusnandar tetapi Ibu Winita E. Kusnandar memutuskan untuk mengembangkan lagi poli kesehatan tersebut dan diubah menjadi klinik yang saat ini bernama Klinik Alita. Diharapkan Klinik Alita dapat meningkatkan pengetahuan masyarakat mengenai kesehatan sebagai sarana untuk membantu pemerintah dalam mewujudkan masyarakat Indonesia yang sejahtera, sehat jasmani dan rohani serta berkomitmen memberikan pelayanan kesehatan yang optimal dan menjunjung tinggi etika pelayanan yang baik dan tepat.

Dalam menjalankan suatu bisnis setiap perusahaan pasti memiliki proses bisnis sistem yang berbeda-beda diantara tiap perusahaam. Pada Klinik Alita proses bisnis sistemnya tidak 
berbeda jauh dengan proses bisnis sistiem klinik pada umumnya dimana proses bisnis sistem pada Klinik Alita masih menggunakan cara manual yakni ditulis tangan.

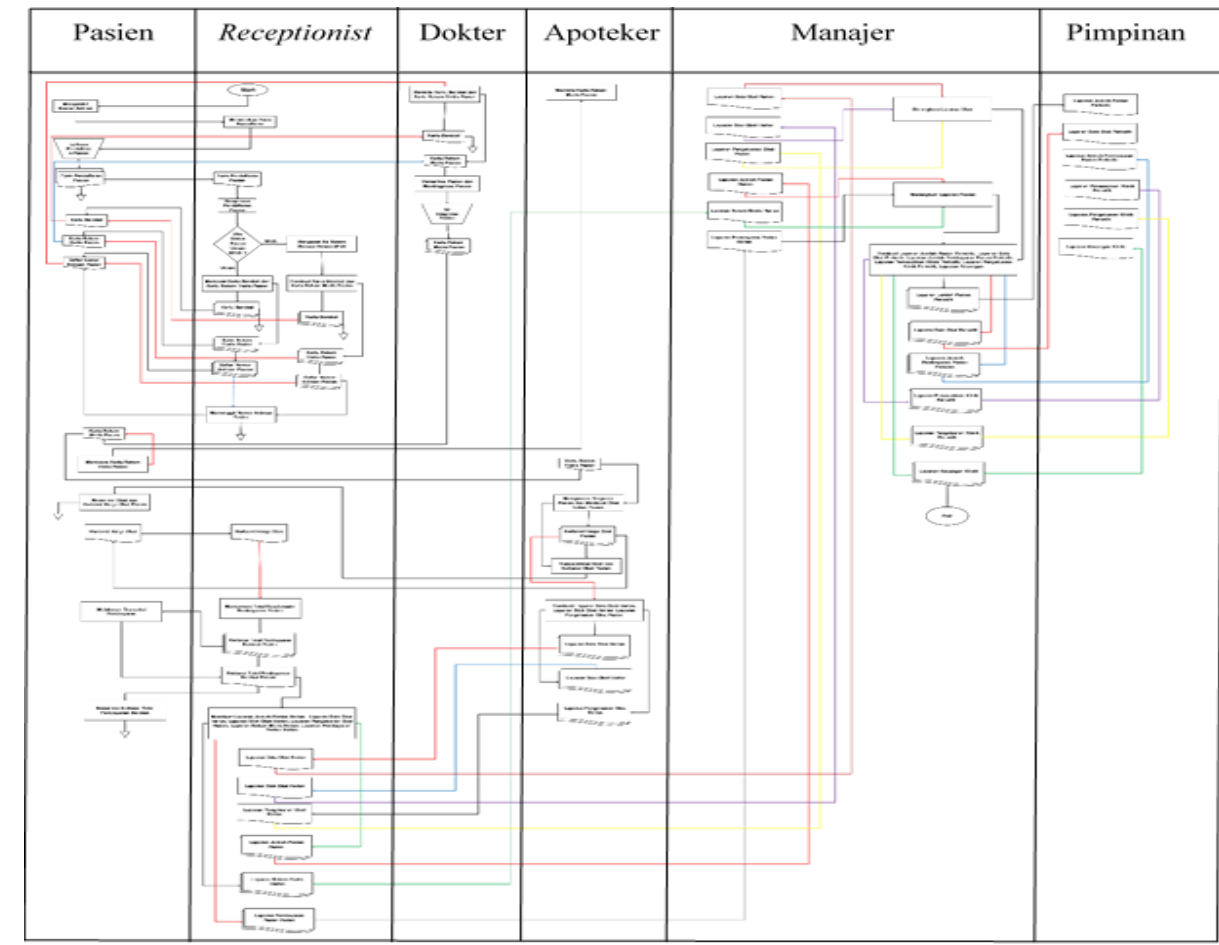

Sumber: Hasil Penelitian (2020)

Gambar 3.Flowmap Proses Bisnis Sistem Berjalan Klinik Alita

Gambar 3 merupakan Proses Bisnis Sistem yang saat ini berjalan pada Klinik Alita sebagai berikut: Pelayanan Poliklinik pada Klinik Alita dimulai dari pasien datang ke Klinik Alita jika pasien yang datang belum pernah berobat ke Klinik Alita maka pasien harus terlebih dahulu mengisi data diri ke receptionist kemudian setelah mengisi data diri maka melakukan pendaftaran yang akan diproses oleh receptionist. Apabila pasien yang datang sebelumnya pernah berobat di Klinik Alita maka tidak perlu lagi mengisi data diri langsung melakukan proses pendaftaran ke receptionist. Receptionist memproses pendaftaran pasien, jika status pasien adalah pasien umum maka akan langsung dibuatkan kartu berobat dan kartu rekam medis pasien lalu memberikan daftar nomor antrean kepada pasien. Jika status pasien adalah BPJS, maka receptionist akan meminta Kartu BPJS pasien dan mengecek ke sistem website resmi BPJS apakah pasien memang betul memiliki BPJS atau tidak, kemudian barulah dibuatkan kartu berobat dan kartu rekam medis pasien lalu memberikan daftar nomor antrean kepada pasien. Receptionist memanggil nomor antrean pasien untuk masuk ke ruangan dokter sesuai dengan poli untuk diperiksa oleh dokter, kemudian pasien memberikan kartu berobat dan kartu rekam medis pasien kepada dokter. Setelah diperiksa oleh dokter, kemudian dokter mengisi diagnosa pasien pada kartu rekam medis pasien lalu diserahkan kepada pasien. Pasien membawa kartu rekam medis dan diserahkan kepada Bagian Apoteker untuk nantinya diberi obat oleh Bagian Apoteker. Bagian Apoteker memproses kartu rekam medis pasien dan membuat obat untuk pasien sesuai dengan diagnosa yang diberikan oleh dokter. Kemudian bagian Apoteker membuat kwitansi harga obat pasien, kemudian menyerahkan obat dan kwitansi harga obat pasien lalu diserahkan kepada pasien. Setelah pasien mengambil obat dan kwitansi harga obat dari Bagian Apoteker, kemudian kwitansi harga obat diserahkan kepada receptionist untuk melakukan proses pembayaran. Pasien memberikan kwitansi harga obat kepada receptionist lalu receptionist memproses pembayaran pasien, kemudian membuat kwitansi total pembayaran berobat pasien. Selanjutnya pasien selanjutnya melakukan transaksi pembayaran kepada receptionist, kemudian receptionist memberikan surat keterangan sakit atau surat keteranan sehat dan memberikan kwitansi total pembayaran berobat pasien kepada pasien. Bagian Apoteker memberikan laporan kepada receptionist tentang data obat yang ada 
meliputi Laporan Data Obat Harian, Laporan Stok Obat Harian, Laporan Pengeluaran Obat Harian. Setelah itu receptionist memberikan laporan kepada manajer tentang pelayanan poliklinik yang ada meliputi Laporan Jumlah Pasien Harian, Laporan Data Obat Harian, Laporan Stok Obat Harian, Laporan Pengeluaran Obat Harian, Laporan Rekam Medis Harian, dan Laporan Pembayaran Pasien Harian. Manajer Klinik memberikan laporan kepada Pimpinan Klinik tentang pelayanan poliklinik yang ada meliputi Laporan Jumlah Pasien Periodik, Laporan Data Obat Periodik, Laporan Jumlah Pembayaran Pasien Periodik, Laporan Pemasukkan Klinik Periodik, Laporan Pengeluaran Klinik Periodik, dan Laporan Keuangan Klinik.

\section{Desain}

Use case diagram menggambarkan cara user berkomunikasi dengan sistem dan berfungsi untuk mengetahui fungsi yang ada didalam sistem, pada gambar 1 menunjukkan proses secara keseluruhan yang terjadi antara aktor dan sistem di Klinik Alita. User sebagai aktor dalam sistem terdiri dari receptionist, pasien, dokter, apoteker, manajer serta pimpinan klinik. Adapun kegiatan sistem antara lain data diri pasien baru, pendaftaran pasien baru, memberikan resep obat dan rekam medis, memberikan bukti pembayaran dan memberikan laporan.

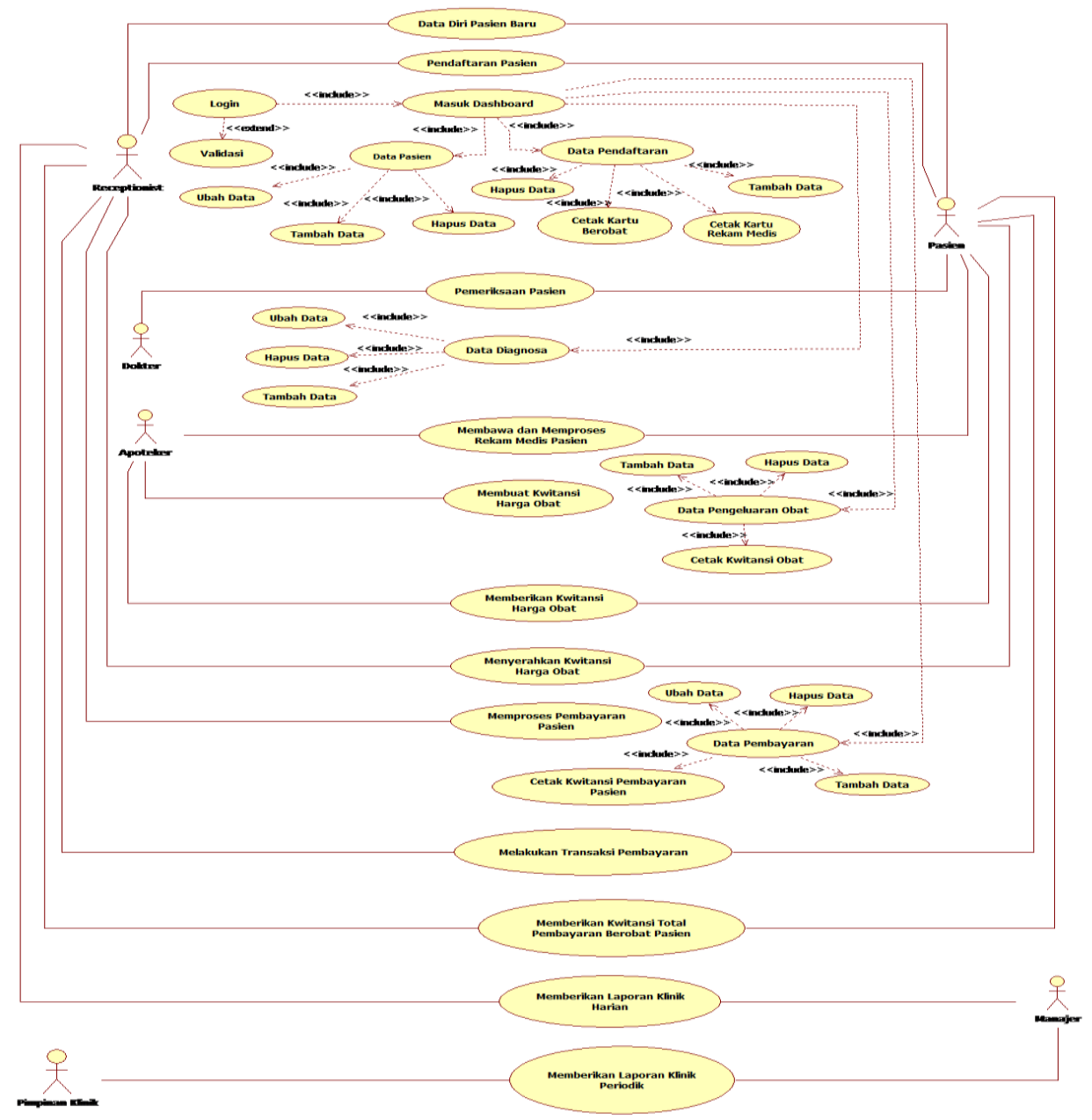

Sumber: Hasil Penelitian (2020)

Gambar 4. Usecase Diagram Sistem Usulan Klinik Alita

Pada tabel 1 merupakan penjelasan dari usecase diagram untuk data pasien, yaitu Proses ini untuk mengolah data pasien yang tersedia mulai dari menambahkan, mengubah, menghapus, mencari data pasien yang ada, mencetak kartu berobat pasien dan mencetak data pasien. Berdasarkan pada skenario kegiatan pelayanan poliklinik di Klinik Alita, selanjutnya dibuat sebuah Activity diagram yang menggambarkan sistem usulan dimana setiap aktivitas dianggap memiliki sebuah rancangan antar muka tampilan serta rancangan menu serta 
rancangan form yang berbeda-beda yang ditampilkan pada perangkat lunak. Gambar 2 bentuk dari sistem usulan dalam rancangan Activity diagram.

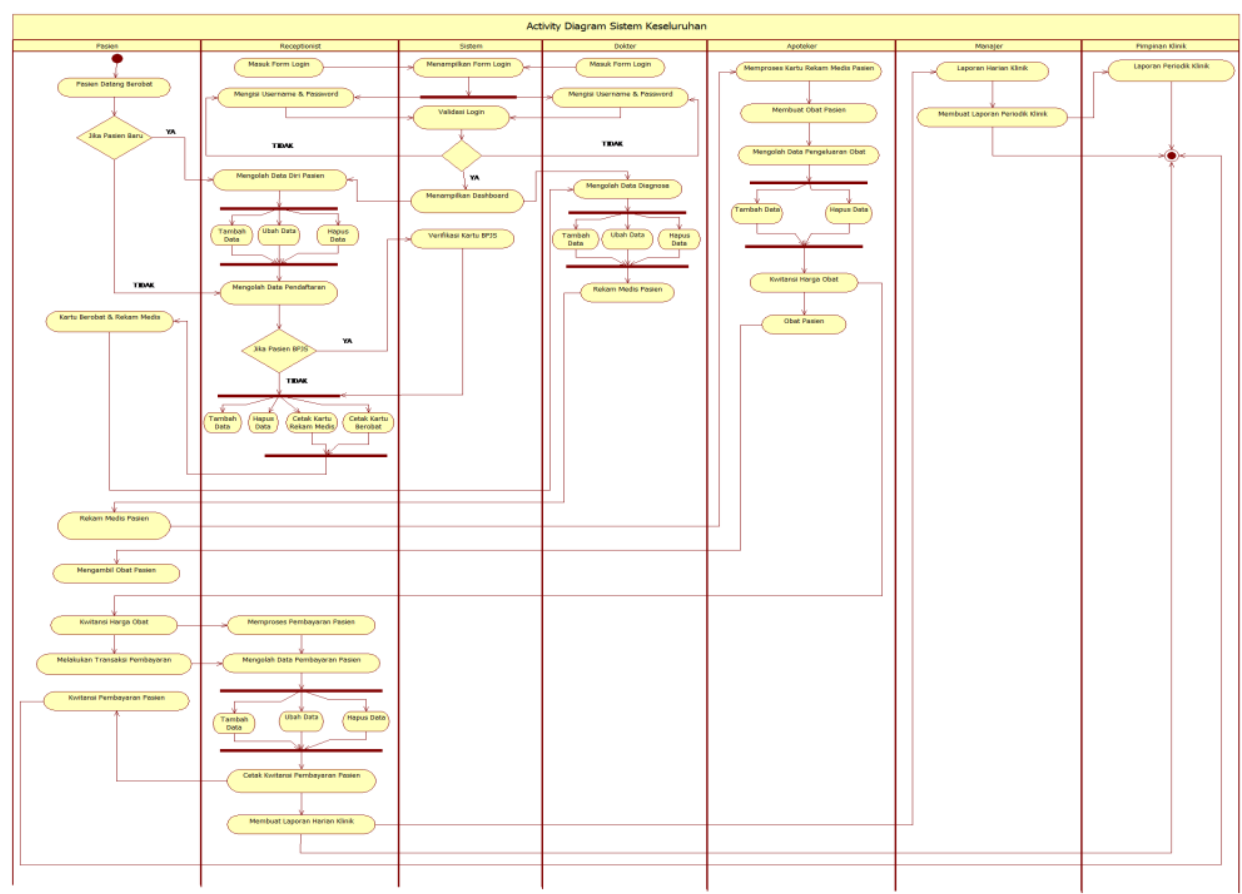

Sumber: Hasil Penelitian (2020)

Gambar 5. Diagram Activity Sistem Usulan klinik Alita

Sistem usulan yang dihasilkan terdiri atas tiga bagian utama yaitu Dashboard terdiri atas Form Pasien, Form Pendaftaran, Form Diagnosa, Form Dokter, dan Form Obat; Menu Transaksi terdiri atas Form Pengeluaran Obat dan Form Pembayaran; Menu Laporan terdiri Atas Form Laporan Jumlah Pasien, Form Laporan Data Obat, Form Laporan Stok Obat, Form Laporan Pengeluaran Obat, Form Laporan Rekam Medis, dan Form Laporan Pembayaran Pasien. Dashboard terdiri dari beberapa menu yakni Pasien, Pendaftaran, Diagnosa, Dokter, dan Obat dimana semua menu tersebut saling terhubung satu sama lain. Pengolahan datanya berupa create, update, dan delete.

Menu transaksi merupakan hasil dari masukkan atau inputan dari Dashboard. Menu transaksi ini tidak dapat bekerja maksimal jika semua data di dalam Dashboard tidak di input sepenuhnya setelah melakukan input data dengan sempurna di Dashboard, menu transaksi bisa bekerja maksimal dimana terdapat pengeluaran obat yang mengambil data dari diagnosa dan obat serta pembayaran yang mengambil data dari pengeluaran obat, pendaftaran, dan dokter.

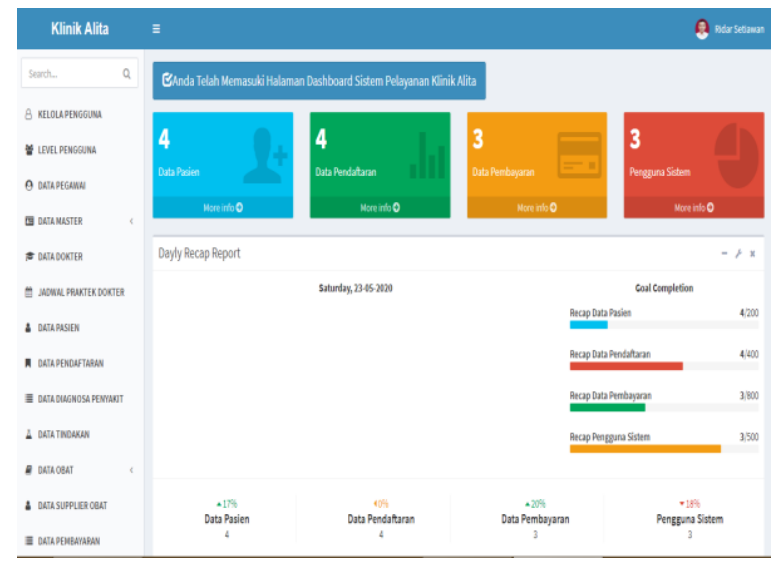

Sumber: Hasil Penelitian (2020)

Gambar 6. Dashboard Pelayanan Poliklinik pada Klinik Alita 
Menu laporan dilakukan oleh receptionist dimana receptionist akan membuat laporan berdasarkan hasil masukkan dari beberapa form, Dimana receptionist bertanggung jawab ata laporan harian Klinik Alita. Setelah laporan tersebut selesai dibuat maka akan langsung diserahkan ke manajer Klinik Alita.

\section{Kesimpulan}

Setelah melakukan penelitian pada perancangan sistem informasi pelayanan poliklinik pada Klinik Alita Rawalumbu Bekasi, maka dihasilkan sebuah aplikasi yang merupakan bentuk dari perbaikan sistem informasi yang selama ini masih dilakukan secara manual menjadi berbasis komputer dan website. Sistem Informasi klinik ini dapat membantu petugas Klinik dalam mengolah data yang ada di Klinik Alita dan mempermudah dalam pembuatan laporan yang akurat dan efesien. Sebagai bentuk pengembangan sistem diwaktu mendatang untuk lebih baik dan lebih sempurna lagi maka ada beberapa saran yang diajukan untuk pengembangan dan perbaikan, yaitu: Diharapkanya sistem yang akan dikembangkan nantinya bisa berupa mobile atau android sehingga jika pasien ingin mendaftar untuk berobat bisa langsung dari smartphone mereka atau ketika mereka ingin melihat jadwal praktek dokter di Klinik Alita.

\section{Referensi}

[1] A. A. Barata, Dasar Dasar Pelayanan Prima. Jakarta: PT Elex Media Komputindo, 2017.

[2] A. Subagja, Membangun Aplikasi dengan Codelgniter dan Database SQL Server. Jakarta: PT Elex Media Komputindo, 2017.

[3] K. Zubaidi, Seri Pemrograman PHP di Ubuntu: Membuat Sistem Informasi Kursus Berbasis Web. Yogyakarta: CV. Andi Offset, 2015.

[4] Supono and V. Putratama, Pemrograman Web dengan menggunakan PHP dan Framework Codelgniter. Yogyakarta: Deepublish, 2018.

[5] H. Fahmi, "Perancangan Sistem Informasi Rekam Medis Di Klinik Griya Medika Menggunakan Metode Prototyping," Permata Indones., vol. 6 No.1, no. November, pp. 29-36, 2015.

[6] Syahrial, "Sistem Informasi Poliklinik Terpadu," Sist. Inf., vol. 5, no. 1, pp. 24-31, 2017.

[7] A. P. Hanifah, Y. Fitrisia, and D. Hajar, "Sistem Informasi Pelayanan Klinik Berbasis Web (Studi Kasus: Klinik Annisa Medika 2)," J. RESTI (Rekayasa Sist. dan Teknol. Informasi), vol. 2, no. 3, pp. 668-673, 2018.

[8] Weli, Aplikasi Kasus Siklus Transaksi Bisnis. Jakarta: Universitas Katolik Indonesia Atma Jaya, 2019.

[9] Tim EMS, Teori dan Praktik PHP-MySQL untuk Pemula. Jakarta: PT Elex Media Komputindo, 2014.

[10] T. S. Jaya and D. K. Widyawati, "Pengembangan E-Market Place Pertanian Dengan Metode Prototype Development of Agricultural E-Marketplace By Prototype Method," Semin. Nas. Pengemb. Teknol. Pertan., pp. 27-34, 2019. 